\title{
Shifting patterns of disparities in unintentional injury mortality rates in the United States, 1999-2016
}

\author{
Cheryl J. Cherpitel ${ }^{1}$, Yu Ye ${ }^{1}$ and William C. Kerr ${ }^{1}$
}

Suggested citation Cherpitel CJ, Ye Y and Kerr WC. Shifting patterns of disparities in unintentional injury mortality rates in the United States, 19992016. Rev Panam Salud Publica. 2021;45:e36. https://doi.org/10.26633/RPSP.2021.36

ABSTRACT Objectives. To analyze changes in racial/ethnic disparities for unintentional injury mortality from 1999-2016. Methods. Mortality data are from the National Center for Health Statistics (NCHS) for all unintentional injuries, analyzed separately by injury cause (motor vehicle accidents [MVA], poisonings, other unintentional) for white, black, and Hispanic populations within four age groups: 15-19, 20-34, 35-54, 55-74 for males and for females.

Results. Rates across race/ethnic groups varied by gender, age and cause of injury. Unintentional injury mortality showed a recent increase for both males and females, which was more marked among males and for poisoning in all race/ethnic groups of both genders. Whites showed highest rates of poisoning mortality and the steepest increase for both genders, except for black males aged 55-74. MVA mortality also showed an increase for all race/ethnic groups, with a sharper rise among blacks, while Hispanics had lower rates than either whites or blacks. Rates for other unintentional injury mortality were similar across groups except for white women over 55, for whom rates were elevated.

Conclusions. Data suggest while mortality from unintentional injury related to MVA and poisoning is on the rise for both genders and in most age groups, blacks compared to whites and Hispanics may be suffering a disproportionate burden of mortality related to MVAs and to poisonings among those over 55 , which may be related to substance use.

Keywords Accidental injuries; mortality; race factors; ethnic inequality; United States.

Life expectancy in the United States (U.S.) has been decreasing since 2014 [1-3], with unintentional injury playing a large role in this phenomenon. Unintentional injury is the third leading cause of death behind heart disease and cancer, and the leading cause among individuals under 45 years of age [4]. A comparison of mortality trends between 2000-2014 with the similarly resourced countries of Canada and Australia found higher mortality rates in the U.S., accounted for primarily by homicides, motor vehicle accidents (MVA) and poisonings, with smaller differences found for falls and suicide [5]. Injury rates in the U.S. have increased from 2000 to 2009 with large increases in suicides, falls and poisonings [6]. The increased rate for suicides has been linked to alcohol during the recession [7] and more specifically to poverty rates [8], while fatal poisonings have been linked to the opiate "epidemic" $[9,10]$.

Among Hispanics, unintentional injury is the leading cause of death for those aged 15-44 in the U.S. and among blacks, the second leading cause for those 15-34 and third leading cause for those 35-54 [6]. A systematic analysis of mortality among those aged 24-64 found increased mortality between 1999-2016 among whites and American Indians / Alaskan Natives (AI/AN), with decreases among blacks, Hispanics and Asian/Pacific Islanders (PI) which ended in 2009-2011 [11]. Across all racial/ethnic groups increased mortality was largely due to external causes including drug overdoses, MVAs, and other unintentional injuries as well as to homicide and suicide. Mortality rates were

\footnotetext{
1 Public Health Institute, Emeryville, United States of America $\square$ Cheryl J.

Cherpitel, ccherpitel@arg.org
}

This is an open access article distributed under the terms of the Creative Commons Attribution-NonCommercial-NoDerivs 3.0 IGO License, which permits use, distribution, and reproduction in any medium, provided the original work is properly cited. No modifications or commercial use of this article are permitted. In any reproduction of this article there should not be any suggestion that PAHO or this article endorse any specific organization or products. The use of the PAHO logo is not permitted. This notice should be preserved along with the article's original URL. 
higher among males than females, although the relative increase in fatal drug overdoses and suicides was greater among females. One study examining poverty and disparities in unintentional injury mortality found those living in highest poverty counties at increased risk for all injury mechanisms except the accidental discharge of firearms [12]. This same study found the population attributable fraction for all unintentional injuries rose form $22 \%$ in 1999 to $35 \%$ in 2012.

One plausible explanation for observed increases in mortality from unintentional injury and related disparities is the overall increase in per capita consumption of alcohol in the U.S., (primarily from spirits and wine consumption) (Figure 1) [13] which is known to have a strong association with both injury morbidity [14] and mortality [15-17]. A review of racial/ethnic differences in injury mortality in the U.S. found the rate of alcohol positivity and intoxication was disproportionately higher, and alcohol-attributable injury overrepresented, among blacks and Hispanics compared to whites [18], and both black and Hispanic males have been found to continue to drink heavily at older ages [19], with a greater risk of alcohol-related consequences [20,21] compared to white males.

Analysis of data from the U.S. National Alcohol Survey (NAS) on risk of a serious lifetime injury found risk increased with the frequency of heavy drinking days for whites, but among blacks, only daily heavy drinkers had an increased risk of injury, while yearly and monthly heavy drinkers were at greater risk among Hispanics, although risk was lower and non-significant for more frequent heavy drinkers [22]. Other NAS data found risk of injury related to drinking prior to the event was significantly elevated for blacks $(R R=1.54)$ and Hispanics $(R R=1.98)$ but not for whites $(R R=.89)$ [23]. Additional analysis of the NAS data found disparity in the risk of alcohol-related injury for Hispanics compared to whites at the same average monthly volume of consumption at lower (3-4 drinks per day) and higher ( $>8$ drinks per day) volume levels, while whites had the highest risk of alcohol-related injury based on the number of $5+$ drinking days, and blacks the lowest risk at all volume levels and 5+ levels when demographic and socioeconomic characteristics were controlled [24].

Racial/ethnic disparities in MVA injury and self-reported driving under the influence (DUI) have also been found, with higher risk of DUI for white males and females compared to blacks and Hispanics [25]. A review of disparities in alcohol-related MVAs found higher rates among whites, but this varied across states [18]. Subjective intoxication and drink size and strength have been found to vary by race/ethnicity [26, 27], and may account for disparities observed in MVA injury and DUI. Blacks have reported needing fewer drinks to feel intoxicated than whites, while Hispanics report more compared to whites [26]. Both blacks and Hispanics have reported higher-strength drinks than whites $[27,28]$ and a larger number of drinks preceding perceived DUI [29].

Given the increase in mortality from unintentional injury and disparities by race/ethnicity which may be accounted

FIGURE 1. US per capita mean liters of ethanol per population aged 15+

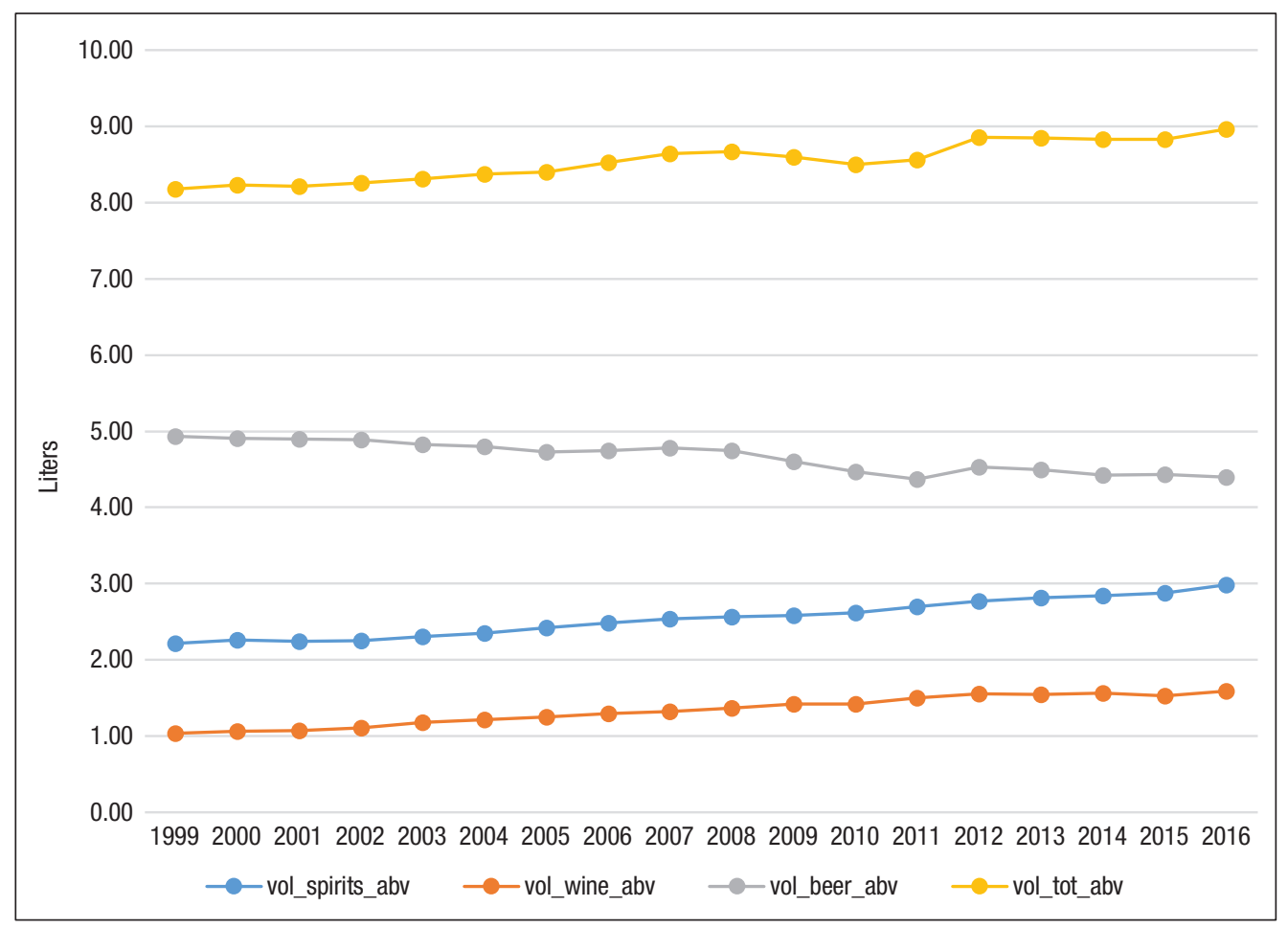


for by disparities in rising per capita consumption in the U.S., reported here is an analysis of shifting patterns in mortality between 1999-2016 from all unintentional injuries, and separately for MVAs, poisonings, and unintentional injuries excluding MVAs and poisonings, separately for males and females by race/ethnicity and age. Highlighted are racial/ ethnic disparities in recent mortality changes across gender and age groups. Unintentional injuries are largely preventable making this an important area for public health intervention including alcohol control policy.

\section{METHODS}

\section{Data}

Annual compressed mortality and population data for 1999-2016 were obtained from the National Center for Health Statistics (NCHS). The NCHS data provide complete pooled annual mortality and population counts by age, gender, race/ ethnicity and cause of death, obtained from death certificates [30]. Cause of death was coded in accordance with the International Statistical Classification of Diseases and Related Health problems, $10^{\text {th }}$ Revision (ICD-10). Population counts are based on bridged-race revised intercensal estimates. Included here is data on mortality for all unintentional injuries, motor vehicle accidents (MVA), poisonings, and unintentional injury excluding MVAs and poisonings. Total unintentional injuries were defined based on ICD 10 codes V01-X59 and Y85-Y86. MVA deaths were from ICD 10 codes V02-V04, V09.0, V09.2, V12-V14，V19.0-V19.2，V19.4-V19.6，V20-V79, V80.3-V80.5, V81.0-V81.1, V82.0-V82.1, V83-V86, V87.0-V87.8, V88.0-V88.8, V89.0 and V89.2. Poisoning injury deaths were based on ICD 10 codes $\mathrm{X} 40-\mathrm{X} 49$, while other unintentional injuries included other land and water transport accidents, falls, exposure to mechanical forces, accidental drowning, exposure to smoke and fire, contact with animals and plants, exposure to forces of nature, etc. This study was exempt from ethical review since it analyzed only aggregate-level data from death certificates which are in the public domain, with no personal identifiers of those deceased.

\section{Data Analysis}

Data were analyzed separately for males and females for the five racial/ethnic groups (white, black, Hispanic, AI/AN and Asian/PI) first, and then focused on whites, blacks and Hispanics. The number of deaths in each specific age group along with population estimates for that group were used to create

FIGURE 2. Changes in US mortality rate of total unintentional injuries (in 100000 ) by race/ethnicity, separately for men and women

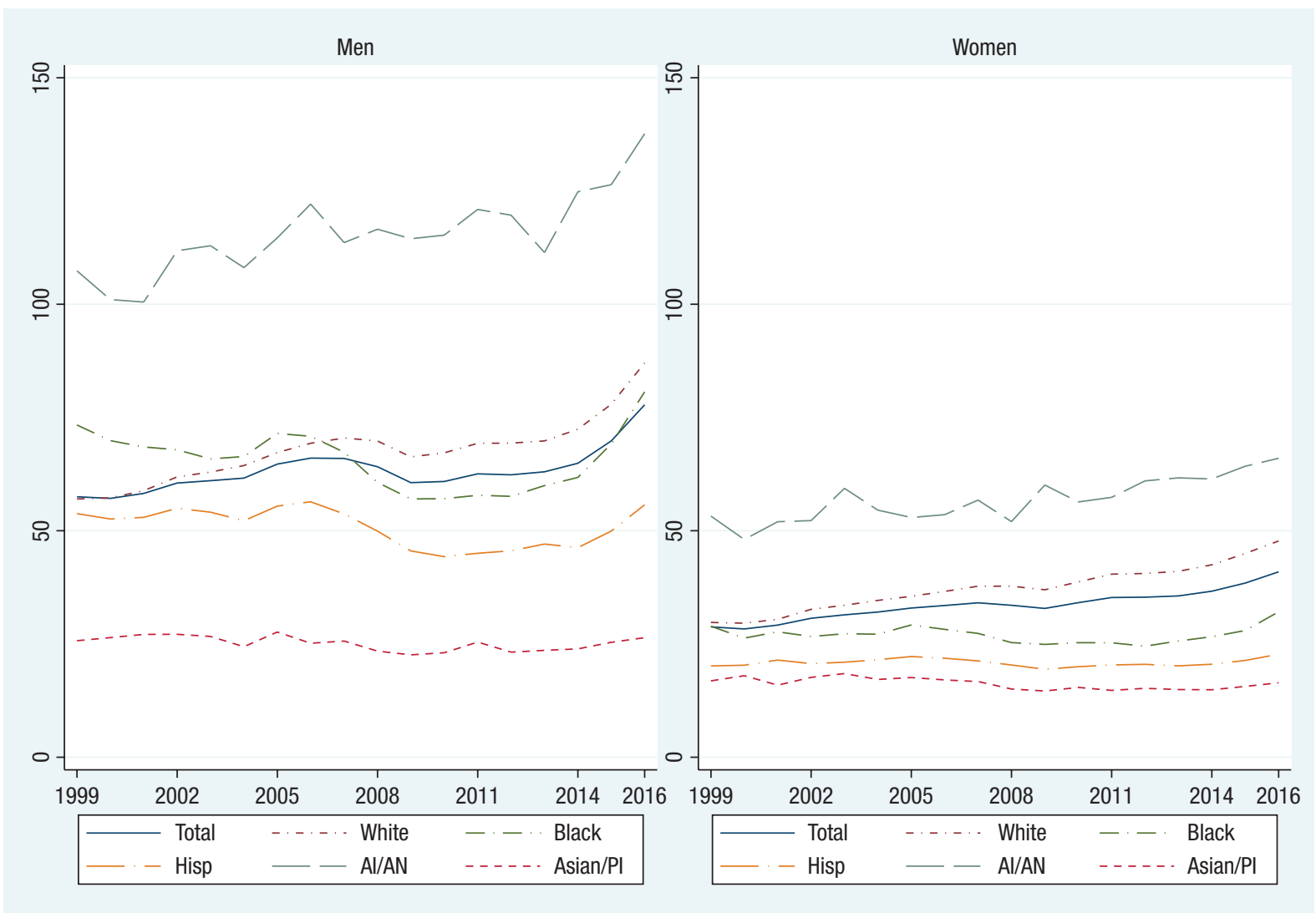

AIN/AN, American Indians/Alaskan Natives; Hisp, Hispanics; PI, Pacific Islanders 
the age-standardized mortality rates, using 2010 U.S. population as the standard, for the total population aged 15 and older. Mortality rates for three age groups (20-34, 35-54, 55-74) were also derived separately, age-standardized within the subgroup. All figures for total mortality were age-adjusted. Mortality rates were calculated as the number of deaths per 100000 U.S. population.

\section{RESULTS}

Figure 2 shows changes in the U.S. mortality rate for all unintentional injuries per 100000 by race/ethnicity, separately for males and females. Females are at lower risk than males across all race/ethnic subgroups. AI/AN were at highest risk while Asian/PI were at lowest risk. An increase is observed beginning in 2014 for males for all but Asian/PI, while some suggestion of an increase also observed among females.

The subsequent figures focus on disparities in unintentional injury mortality among whites, blacks and Hispanics for whom rates are more similar but with some observed convergence and divergence. Figure 3a shows the mortality rate for MVAs among males by race/ethnicity and age group. Blacks appear to be at highest risk followed by whites and then Hispanics, with a decrease observed for all three groups beginning in 2007, and most pronounced among Hispanics, followed by an increase in 2014 for all three race/ethnic subgroups. Rates for fatal MVSs are highest for those 20-34 where rates for Hispanics surpass those for whites.

Figure $3 b$ shows mortality rates among females, where rates for fatal MVA are greatest for whites followed by blacks and Hispanics in all age groups except the oldest where rates for all three race/ethnic subgroups converge. A decrease is generally observed, followed by an increase (in all but the oldest age group) in 2014, where rates for blacks surpass that for whites.

Figure 4 shows changes in poisoning mortality rates. Risk of fatal poisoning for males (Figure 4a) is highest for whites in all but the oldest age group, and most pronounced in the 20-34 year old age group, where rates for blacks and Hispanics converge. Rates for all race/ethnic and age subgroups show

FIGURE 3a. Changes in US male mortality rate of motor vehicle accident (MVA, in 100000$)$ for white, black and Hispanics, by age groups

Total $(15-85+)$

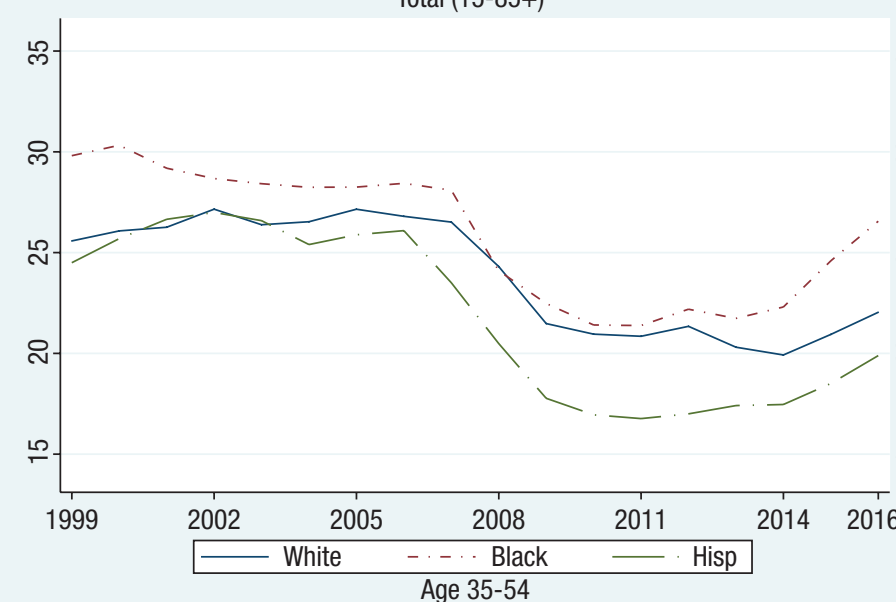

Age 20-34

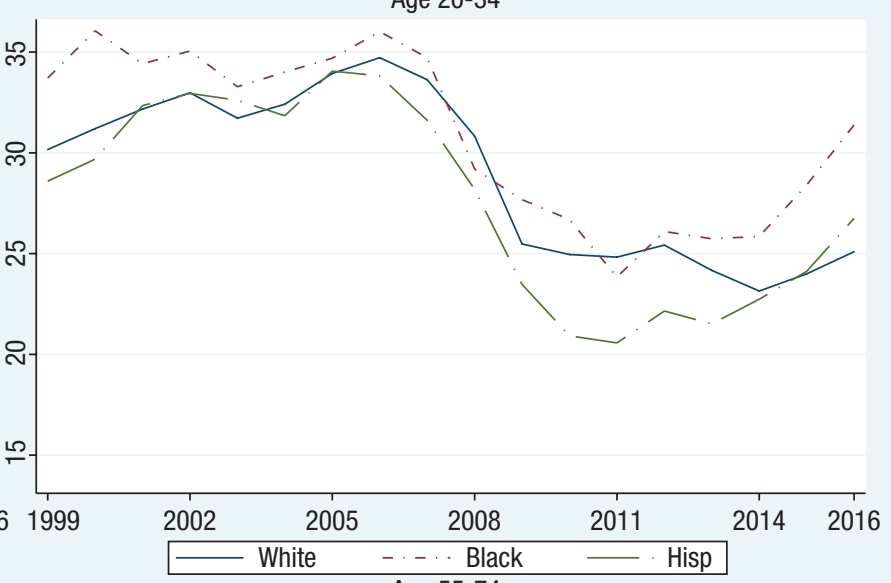

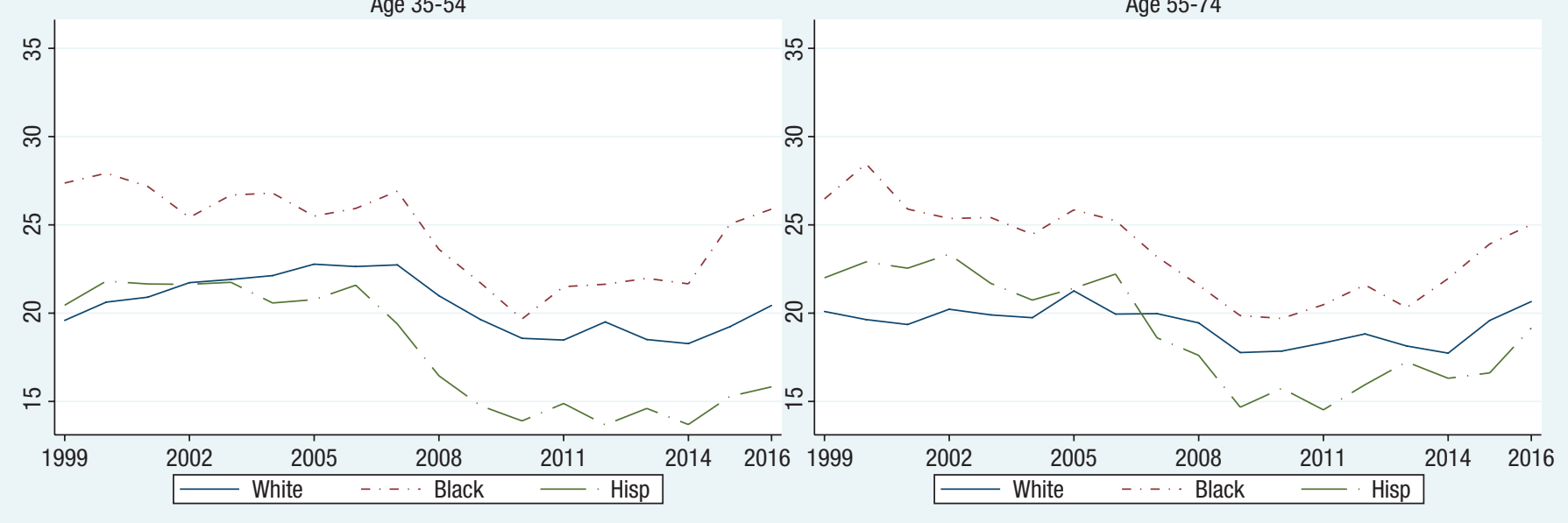

Hisp, Hispanics. 
FIGURE 3b. Changes in US female mortality rate of motor vehicle accident (MVA, in 100 000) for white, black and Hispanics, by age groups

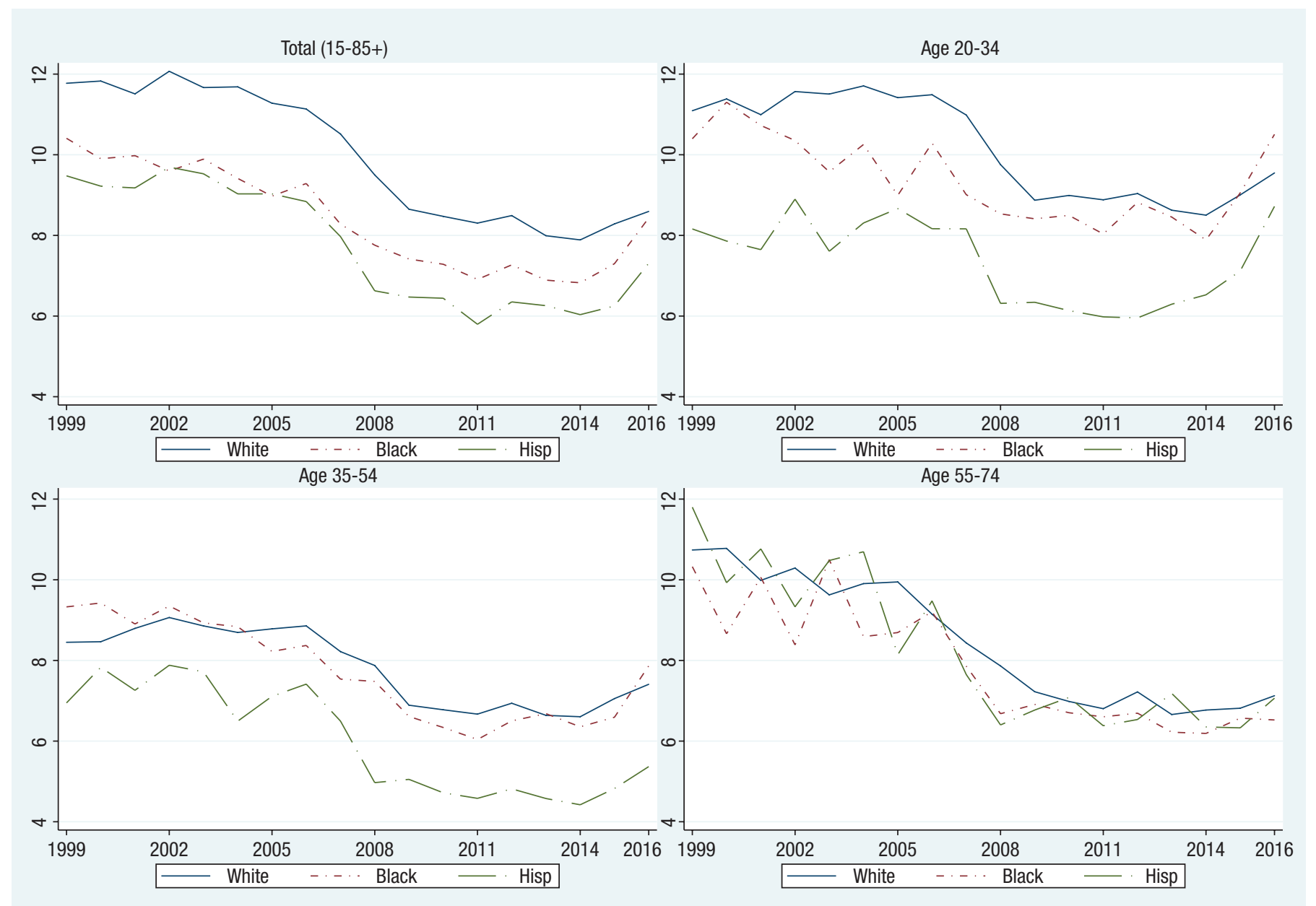

Hisp, Hispanics.

an increase and is most marked among whites in the 20-34 age group. Rates are higher for blacks than whites and Hispanics in the 55-74 age group, and show a steep increase similar to that for 20-34 year old white males.

Poisoning fatalities for females also showed sharp increases, although rates are less than for males (Figure $4 b$ ). White females are at highest risk in all but the oldest age group, followed by blacks and then Hispanics. In the 55-74 age group rates for blacks converge with and supersede those for whites.

Rates for fatal unintentional injury, excluding MVA and poisonings, do not show the increases found for the other fatalities among males (Figure 5a). Rates across race/ethnic subgroups tend to converge in all but the oldest age group where rates for Hispanics are below that for whites and blacks. A similar pattern is seen for females (Figure $5 b$ ) with near convergence in the 20-34 and 35-54 age groups, although Hispanics tend to have slightly lower rates than whites or blacks. In the oldest age group rates for white females surpassed that for blacks and Hispanics and appear to be increasing.

\section{DISCUSSION}

The study explored recent changes and disparities in unintentional injury mortality by cause among racial/ethnic and age groups in the US. While AI/AN had the highest rates of injury mortality for all causes and Asian/PI the lowest rates, rates for whites, blacks and Hispanics were more similar with some recent convergence and divergence in rates, and varied by injury cause, gender and age group. Overall, unintentional injury mortality shows a recent increase across all race/ethnicity and age groups, largely coming from poisonings for both males and females and from MVAs for males and females under age 55 .

The increase in poisoning mortality can most likely be attributed to the recent rise in overdose fatalities from opioids and prescription pain relievers [31-33]. Whites show the highest rates of poisoning mortality and the steepest increase for both genders except among those aged 55-74, where for males, blacks show the largest risk and steepest increase, and among females rates for blacks converged with and surpassed that of whites. 
FIGURE 4a. Changes in US male mortality rate of poisoning injuries (in 100000 ) for white, black and Hispanics, by age groups

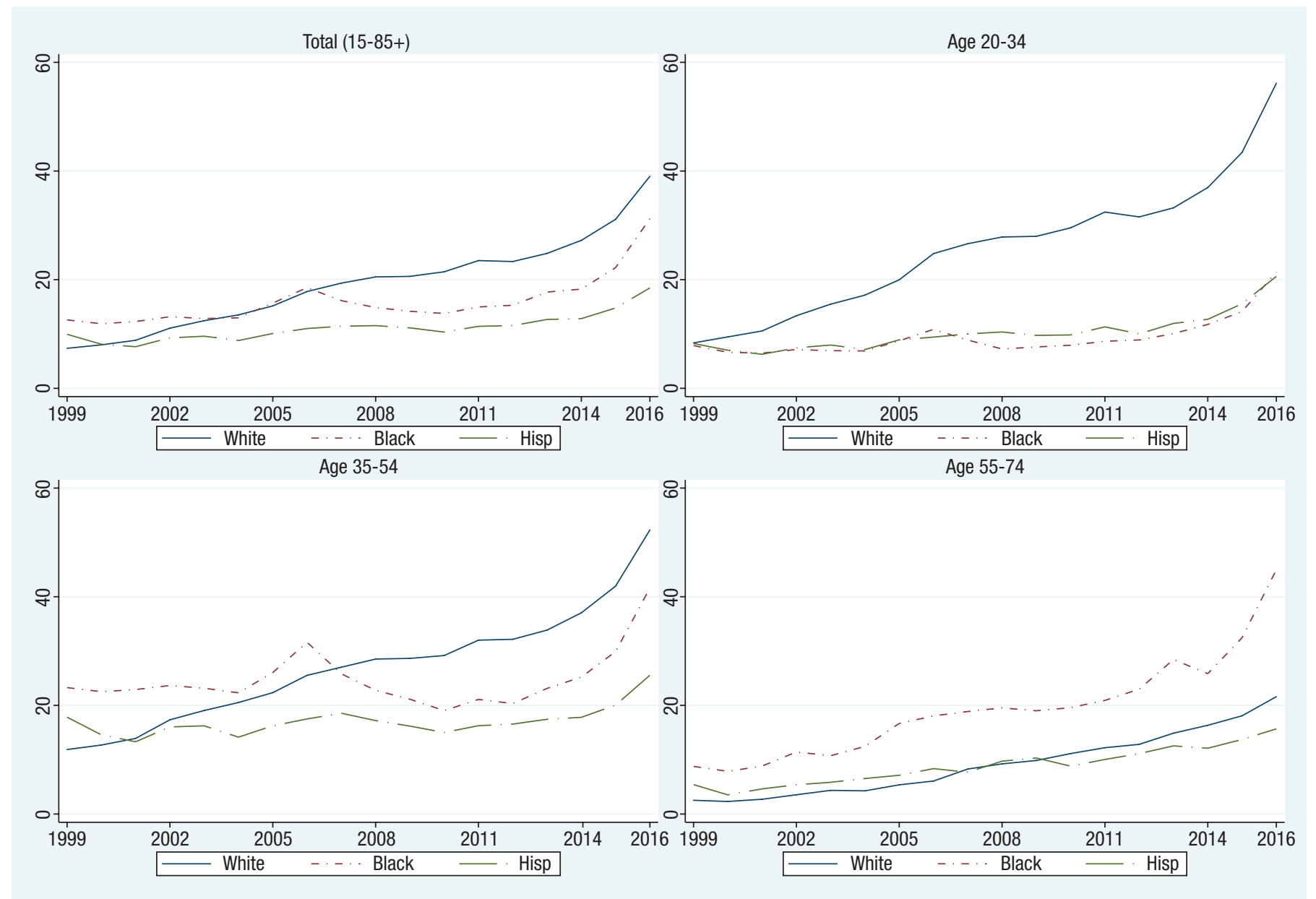

Hisp, Hispanics.

Drug poisoning mortality rates (2006-2015) among adolescents and young adults aged 15 to 24 has also been found to be highest for whites [34], and a marked increase in all-cause mortality between 1999 and 2013 was observed for middle-aged whites, which was largely accounted for by increasing death rates from alcohol and drug poisonings, as well as suicide [35].

Other important changes in mortality rates have emerged, which may be due to rising per capita consumption of alcohol in the U.S. [13]. At the same time underage drinking has declined [36], highlighting increased drinking among middle-aged and older adults [37]. Cirrhosis mortality rates increased in the U.S. by $65 \%$ between 1999 and 2016, with whites, AIs and Hispanics, and those aged 25-34 experiencing the greatest relative increase [38]. Alcohol-related mortality was also found to increase substantially over this period. [39] Further, mortality due to alcohol use disorders, while showing an overall decrease in the U.S. between 1980, the peak of U.S. $20^{\text {th }}$ century alcohol consumption, and 2014, showed a significant increase in two-thirds of American counties [40]. The current study's documentation of trends and disparities over the 1999-2016 period will be followed by state-level panel analyses of risk relationships between estimates of alcohol volume and binge drinking with these unintentional injury mortality cause groups by gender for black, white and Hispanic utilizing various methods including causal inference models with alcohol policies as instrumental variables.

While MVA mortality also appears to be on the rise among both males and females, in all but the oldest age group, and across all race/ethnic subgroups, the data suggest a recent sharper rise for blacks of both genders. While blacks have been found to have lower rates of fatal MVA [18] and to report needing fewer drinks to feel intoxicated [26], they also report higher strength drinks and a larger number of drinks prior to a perceived DUI [29]. Our data do not support previous reports of lower rates of fatal MVA among blacks. Rates appear to be higher for blacks compared to whites among males in all age groups and to have recently superseded white rates for females aged 20-55.

For other unintentional causes of injury fatality, rates are similar across race/ethnic subgroups for both genders among those aged less than 55. Among those aged 55 and over, rates for whites appear to be increasing, possibly reflecting an increase 
FIGURE 4b. Changes in US female mortality rate of poisoning injuries (in 100000 ) for white, black and Hispanics, by age groups

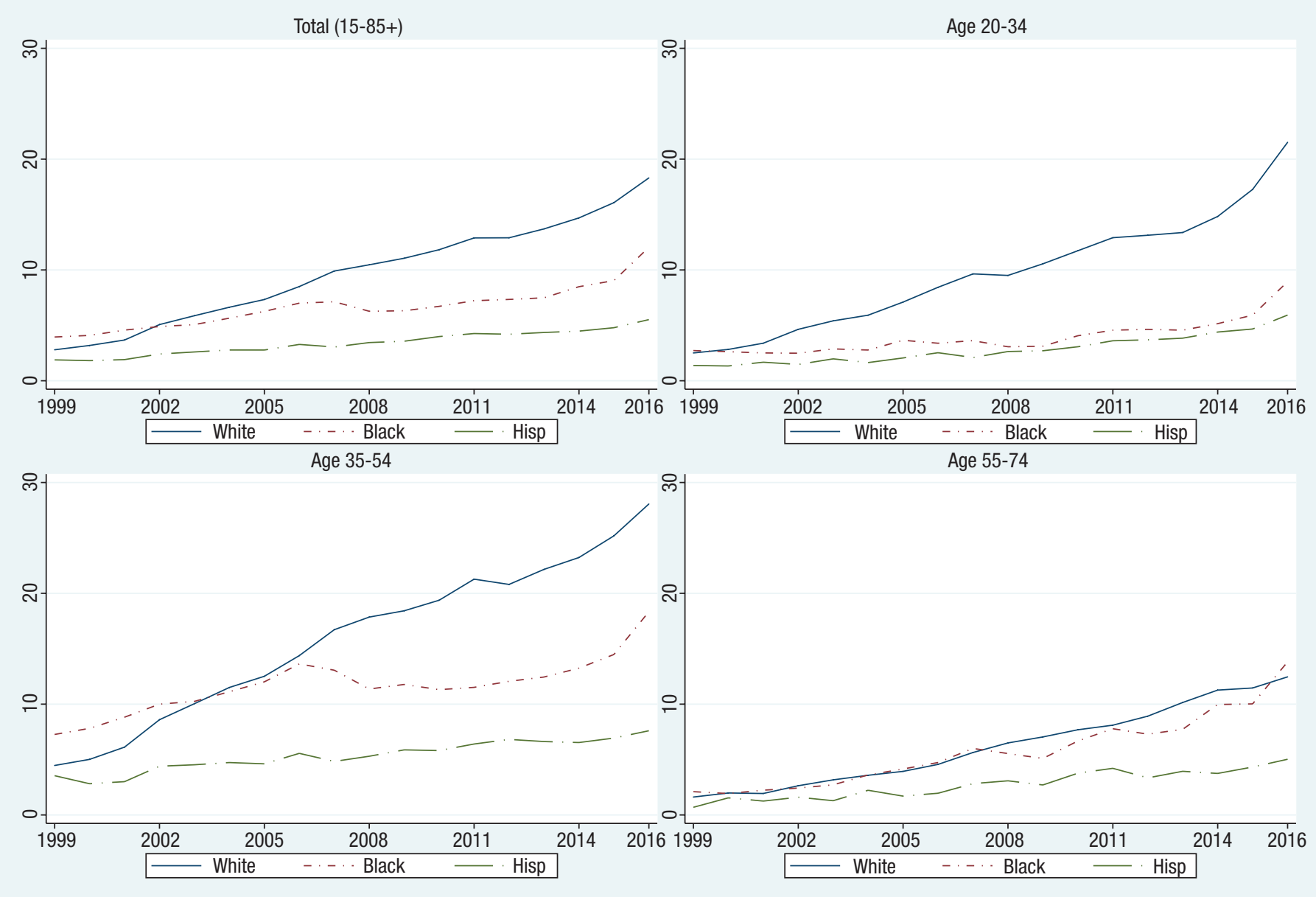

Hisp, Hispanics.

in fall mortality, especially among white females who are more prone to osteoporosis than black or Hispanic females. In contrast, black and Hispanic rates have declined over the period for both men and women. Disparities in rates for blacks 35-54 and particularly 55-74 have equalized with or fallen below rates for whites between 2007 and 2010. This elimination or reversal of black/white disparities in unintentional injury mortality and sub-types of poisonings and other causes represents an important shift in injury mortality risk and is likely driven by changes in harmful alcohol and drug use with rates rising more among whites over this period.

One potential limitation of this study is that a comparison of mortality rates across racial/ethnic groups may be subject to bias due to misclassification and undercounting [41]. Death rates for Hispanics should be interpreted with caution because of inconsistencies in reporting on death certificates. Information included on the death certificate about the race and Hispanic ethnicity of the decedent is reported by the funeral director as provided by an informant, often the surviving next of kin or, in the absence of an informant, on the basis of observation. On the other hand, race and ethnicity information from the census is by self-report. To the extent that race and Hispanic origin are inconsistent between these two data sources, death rates will be biased [30]. Studies have shown underreporting on death certificates of Hispanic decedents, as well as undercounts in censuses [42-44].

Nevertheless, these data suggest that while mortality from intentional injury related to MVA and poisoning is on the rise for both genders and in most age groups, blacks may be suffering a disproportionate burden of mortality related to MVAs and to poisonings among those over 55 . Increasing socioeconomic disparity has been found for all unintentional injuries [12] and widening area-based disparities for all-cause mortality $[45,46]$. Given the increasing trends in socioeconomic inequality in the US, and the fact that these data only include rates through 2016, larger disparities in unintentional injury mortality than those found here is likely and also likely to continue into the future.

These data support the reported mortality toll taken by the opioid epidemic, which is affecting all race/ethnic subgroups 
FIGURE 5a. Changes in US male mortality rate of other unintentional injuries (in 100000 ) for white, black and Hispanics, by age groups

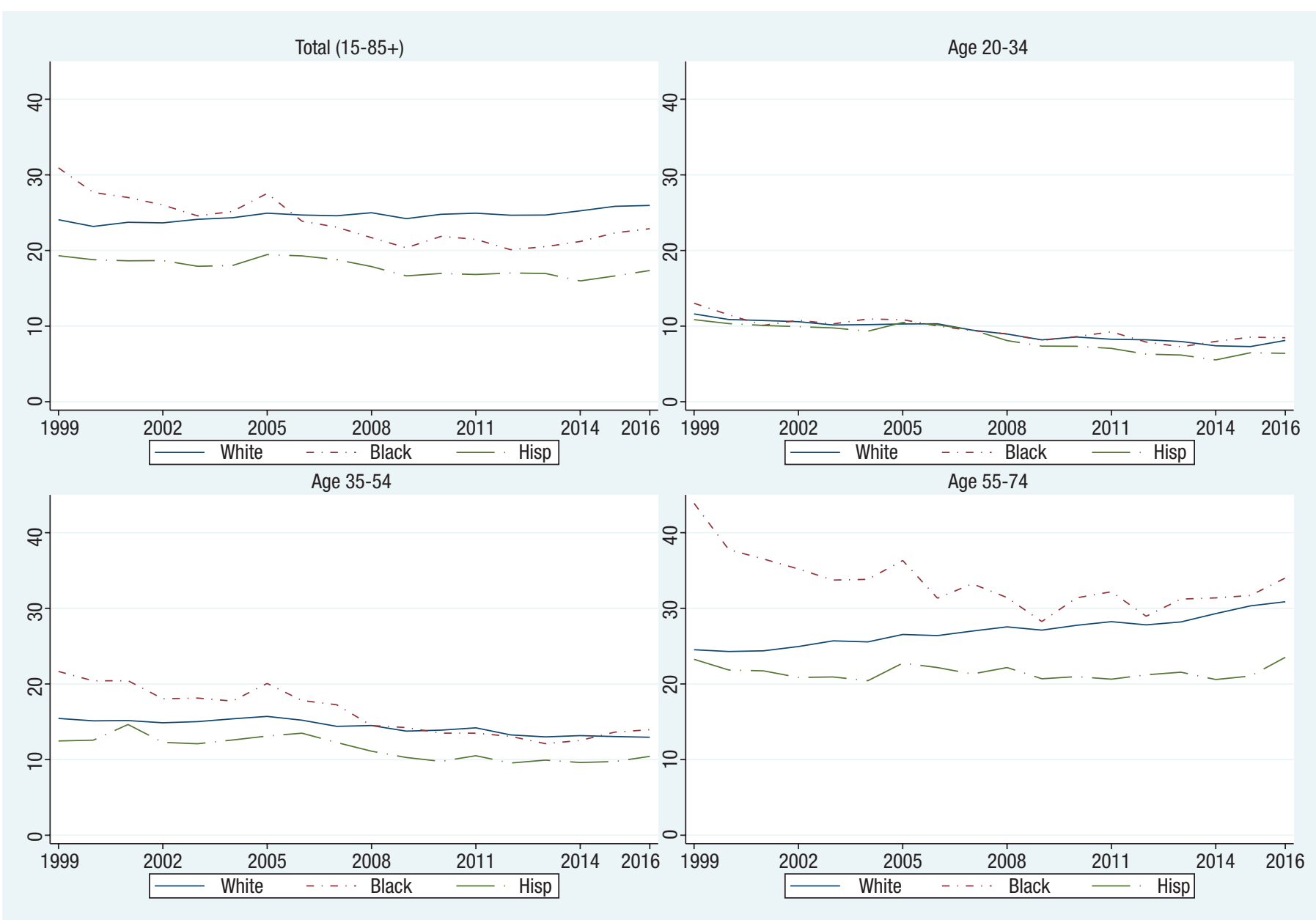

Hisp, Hispanics.

of both genders, but may be disproportionately affecting older blacks. These data also suggest the increase in unintentional injury fatality observed in the most recent years, especially for MVAs, may be due to the rising per capita consumption of alcohol. Most unintentional injuries are preventable making this an important area for public health interventions including alcohol control policy. Establishing which policies are most effective at minimizing harms due to alcohol has been a topic of great attention and debate [47-49]. The World Health Organization (WHO) "best buys" include tax increases, restricted access to retailed alcohol, and bans on alcohol advertising as the policies that provide the most impact and cost effectiveness [50]. In the U.S., however, specific excise taxes on alcohol are based on the volume of alcohol sold and not on price, and have consequently experienced substantial decline over time with inflation [51, 52], suggesting this as a key area for alcohol policy intervention. Strengthening of specific policies targeting MVAs, particularly reducing the per se blood alcohol concentration limit to $0.05 \mathrm{~g} / \mathrm{dl}$ from $0.08 \mathrm{~g} / \mathrm{dl}$ and increasing the use of ignition interlock devices for offenders, could also have substantial impacts on alcohol related-mortality [53].

Authors contributions. YY and WK designed the study, CC and WK conducted the literature search, YY conducted the statistical analysis, CC and YY wrote the first draft of the manuscript. All authors revised the manuscript and approved the final version.

Funding. Supported by an Alcohol Research Center grant from the U.S. National Institute on Alcohol Abuse and Alcoholism (P50 AA005595).

Disclaimer. The views and opinions in the manuscript are the authors' and do not necessarily reflect the opinion or policy of the RPSP/PAJPH and/or PAHO. 
FIGURE 5b. Changes in US female mortality rate of other unintentional injuries (in 100000 ) for white, black and Hispanics, by age groups

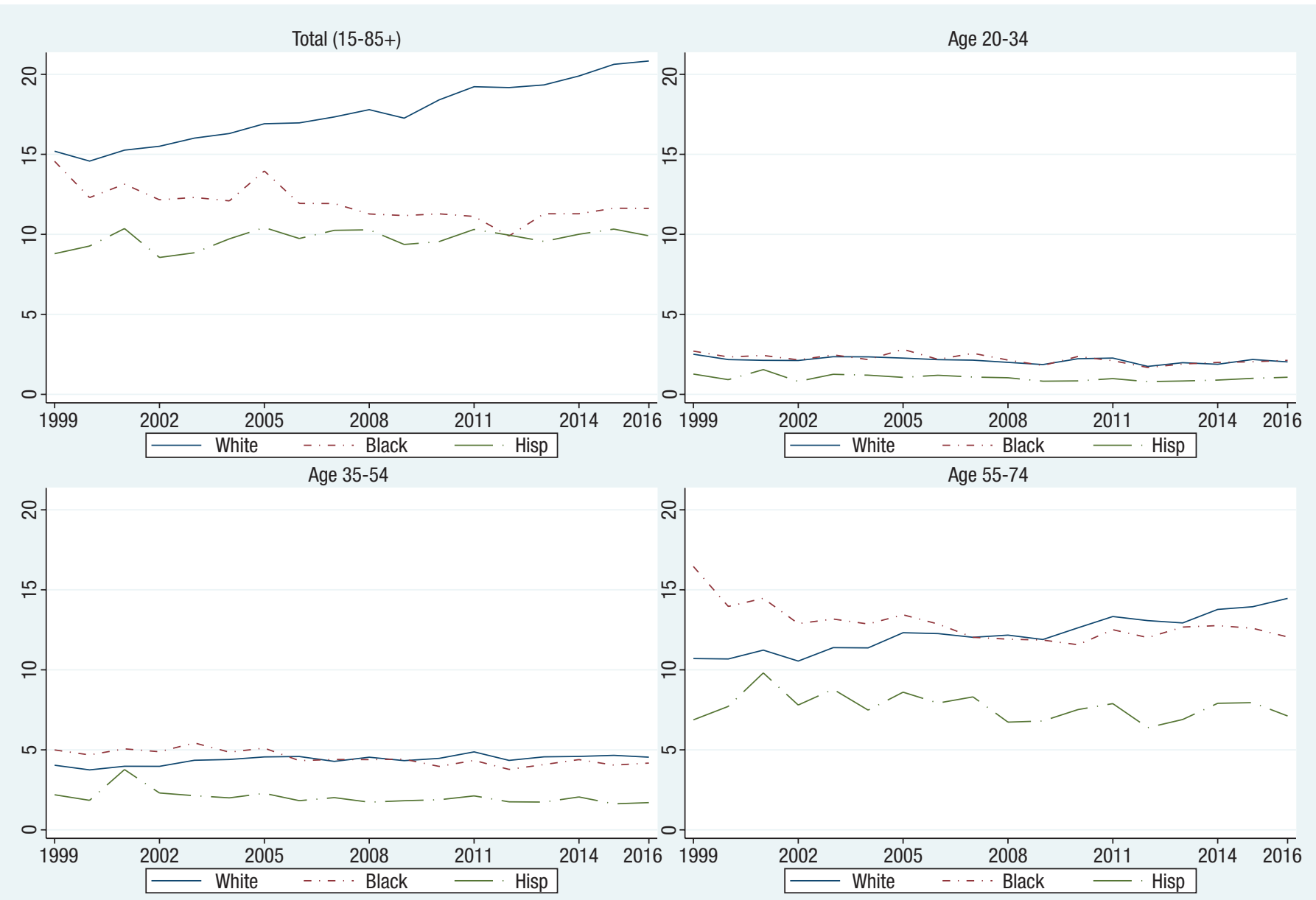

Hisp, Hispanics.

\section{REFERENCES}

1. Murphy SL, Xu J, Kochanek KD, Curtin SC, Arias E. Deaths: final data for 2015. Natl Vital Stat Rep. 2017 November;66(6):1-75.

2. Kochanek KD, Murphy SL, Xu J, Arias E. Mortality in the United States, 2016. NCHS Data Brief, No. 293. Hyattsville, MD: National Center for Health Statistics; 2017.

3. Curtin SC, Arias E. Mortality trends by race and ethnicity among adults aged 25 and over: United States, 2000-2017. Hyattsville, MD: National Center for Health Statistics; 2019.

4. Heron M. Deaths: Leading Causes for 2016. Natl Vital Stat Rep. 2018 July 26;67(6)

5. Mack KA, Clapperton AJ, Macpherson A, Sleet DA, Newton D, Murdoch J, et al. Trends in the leading causes of injury mortality, Australia, Canada and the United States, 2000-2014. Can J Public Health. 2017 June;108(2):e185-e91.

6. Rockett IRH, Regier MD, Kapusta ND, Coben JH, Miller TR, Hanzlick RL, et al. Leading causes of unintentional and intentional injury mortality: United States, 2000-2009. Am J Public Health. 2012 November;102(11):e84-e92.

7. Kaplan MS, Huguet N, Caetano R, Giesbrecht N, Kerr WC, McFarland $\mathrm{BH}$. Heavy alcohol use among suicide decedents relative to a nonsuicide comparison group: gender-specific effects of economic contraction. Alcohol Clin Exp Res. 2016 July;40(7):1501-6.
8. Kerr WC, Kaplan MS, McFarland BH, Mueller-Williams AC, Caetano R, Giesbrecht N. Analyses of economic conditions, suicide and alcohol-related suicide in the US from 2006-2015. American Public Health Association Annual Meeting and Expo. San Diego, CA. November 10-14; 2018.

9. Miech R, Koester S, Dorsey-Holliman B. Increasing US mortality due to accidental poisoning: the role of the baby boom cohort. Addiction. 2011 April;106(4):806-15.

10. Dowell D, Arias E, Kochanek K, Anderson R, Guy Jr. GP, Losby $\mathrm{JL}$, et al. Contribution of opioid-involved poisoning to the change in life expectancy in the United States, 2000-2015. JAMA. 2017 September;318(11):1065-7.

11. Woolf SH, Chapman DA, Buchanich JM, Bobby KJ, Zimmerman EB, Blackburn SM. Changes in midlife death rates across racial and ethnic groups in the United States: systematic analysis of vital statistics. BMJ. 2018;362:k3096.

12. Karb RA, Subramanian SV, Fleegler EW. County poverty concentration and disparities in unintentional injury deaths: a fourteen-year analysis of 1.6 milion U.S. fatalities. PLoS ONE. 2016 May;11(5):e0153516.

13. Martinez P, Kerr WC, Subbaraman M, Roberts SCM. New estimates of the mean ethanol content of beer, wine, and spirits sold 
in the United States show a greater increase in per capita alcohol consumption than previous estimates. Alcohol Clin Exp Res. 2019 March;43(3):509-21.

14. Cherpitel CJ, Ye Y, Bond J, Borges G, Monteiro M. Relative risk of injury from acute alcohol consumption: modeling the dose-response relationship in emergency department data from 18 countries. Addiction. 2015 February;110(2):279-88.

15. Andreuccetti G, Leyton V, Lemos NP, Miziara ID, Ye Y, Takitane J, et al. Alcohol use among fatally injured victims in São Paulo, Brazil: bridging the gap between research and health services in developing countries. Addiction. 2017 April;112(4):596-603.

16. Darke S. The toxicology of homicide offenders and victims: a review. Drug Alcohol Rev. 2010 March;29(2):202-15.

17. Kelly E, Darke S, Ross J. A review of drug use and driving: epidemiology, impairment, risk factors and risk perceptions. Drug Alcohol Rev. 2004 September;23(3):319-44.

18. Keyes KM, Liu XC, Cerda M. The role of race/ethnicity in alcohol-attributable injury in the United States. Epidemiol Rev. 2012 January;34(1):89-102.

19. Caetano R, Kaskutas LA. Changes in drinking patterns among whites, blacks and Hispanics: 1984-1992. J Stud Alcohol. 1995 September;56(5):558-65.

20. Galvan FH, Caetano R. Alcohol use and related problems among ethnic minorities in the United States. Alcohol Res Health. 2003;27(1):89-94.

21. Mulia N, Ye Y, Greenfield TK, Zemore SE. Disparities in alcoholrelated problems among white, black, and Hispanic Americans. Alcohol Clin Exp Res. 2009 April;33(4):654-62.

22. Kerr WC, Ye Y, Cherpitel CJ. Racial/ethnic disparities in the risk of injury related to the frequency of heavy drinking occasions. Alcohol Alcohol. 2015 September;50(5):573-8.

23. Cherpitel CJ, Ye Y. Differences in risk of injury in the U.S. general population by injury treatment type: data from the 1995-2010 National Alcohol Surveys. Alcohol Clin Exp Res. 2014 April;38(4):1094-9.

24. Cherpitel CJ, Ye Y, Kerr W. Relationship of usual volume and heavy consumption to risk of alcohol-related injury: racial/ethnic disparities in four U.S. National Alcohol Surveys. J Stu Alcohol Drugs. 2016 January;77(1):58-67.

25. Caetano R, McGrath C. Driving under the influence (DUI) among U.S. ethnic groups. Accid Anal Prev. 2005 March;37(2):217-24.

26. Kerr WC, Greenfield TK, Midanik LT. How many drinks does it take you to feel drunk? Trends and predictors for subjective drunkenness. Addiction. 2006 October;101(10):1428-37.

27. Kerr WC, Patterson D, Greenfield TK. Differences in the measured alcohol content of drinks between black, white and Hispanic men and women in a US national sample. Addiction. 2009 September;104(9):1503-11.

28. Caetano R, Mills BA, Harris TR. Hispanic Americans Baseline Survey (HABLAS) effects of container size adjustments on estimates of alcohol consumption across Hispanic national groups. J Stu Alcohol Drugs. 2012 January;73(1):120-5.

29. Kerr WC, Greenfield TK. Racial/ethnic disparities in the selfreported number of drinks in 2 hours before driving becomes impaired. Am J Public Health. 2015 July;105(7):1409-14.

30. National Center for Health Statistics. Compressed Mortality File, 1999-2016 (machine readable data file and documentation, CD-ROM Series 20, No. $2 \mathrm{v}$ ) as compiled from data provided by the 57 vital statistics jurisdictions through the Vital Statistics Cooperative Program. Hyattsville, MD: National Center for Health Statistics; 2017.

31. Volkow ND, McLellan AT. Opioid abuse in chronic pain-misconceptions and mitigation strategies. N Engl J Med. 2016 March 31;374(13):1253-63.

32. West NA, Severtson SG, Green JL, Dart RC. Trends in abuse and misuse of prescription opioids among older adults. Drug Alcohol Depend. 2015 April 1;149:117-21.

33. Scholl L, Seth P, Kariisa M, Wilson N, Baldwin G. Drug and opioidinvolved overdose deaths--United States, 2013-2017. Morbidity and Mortality Weekly Report (MMWR). 2018 January;67(5152):1419-27. doi: http://dx.doi.org/10.15585/mmwr.mm675152e1.

34. Ali B, Fisher DA, Miller TR, Lawrence BA, Spicer RS, Swedler DI, et al. Trends in drug poisoning deaths among adolescents and young adults in the United States, 2006-2015. J Stu Alcohol Drugs. 2019 March;80(2):201-10.
35. Case A, Deaton A. Rising morbidity and mortality in midlife among white non-Hispanic Americans in the 21st century. Proc Natl Acad Sci U S A. 2015 December 8;112(49):15078-83.

36. Chen CM, Yoon Y-H, Faden VB. Trends in underage drinking in the United States, 1991-2015 [Surveillance Report \#107]: National Institute on Alcohol Abuse and Alcoholism; 2017.

37. Han BH, Moore AA, Ferris R, Palamar JJ. Binge drinking among older adults in the United States, 2015 to 2017. J Am Geriatr Soc. 2019 October;67(10):2139-44.

38. Tapper EB, Parikh ND. Mortality due to cirrhosis and liver cancer in the United States, 1999-2016: observational study. BMJ. 2018;362:k2817.

39. White AM, Castle I-JP, Hingson RW, Powell PA. Using death certificates to explore changes in alcohol-related mortality in the United States, 1999 to 2017. Alcohol Clin Exp Res. 2020 January;44(1):178-87.

40. Dwyer-Lindgren L, Bertozzi-Villa A, Stubbs RW, Morozoff C, Shirude S, Unützer J, et al. Trends and patterns of geographic variation in mortality from substance use disorders and intentional injuries among US counties, 1980-2014. JAMA. 2018 March;319(10): 1013-23.

41. Arias E, Schauman WS, Eschbach K, Sorlie PD, Backlund E. The validity of race and Hispanic origin reporting on death certificates in the United States. Vital Health Stat 2. 2008;148:1-23.

42. Sorlie PD, Rogot E, Johnson NJ. Validity of demographic characteristics on the death certificate. Epidemiology. 1992 March;3(2):181-4.

43. Rosenberg HM, Maurer JD, Sorlie PD, Johnson NJ, MacDorman MF, Hoyert DL, et al. Quality of death rates by race and Hispanic origin: a summary of current research, 1999 Hyattsville, MD: National Center for Health Statistics; 1999.

44. Arias E, Eschbach K, Schauman WS, Backlund EL, Sorlie PD. The Hispanic mortality advantage and ethnic misclassification on US death certificates. Am J Public Health. 2010;100(1):S171-7.

45. Singh GK, Siahpush M. Widening socioeconomic inequalities in US life expectancy, 1980-2000. Int J Epidemiol. 2006 August;35(4):969-79.

46. Singh GK, Daus GP, Allender M, Ramey CT, Martin EK, Perry C, et al. Social determinants of health in the United States: addressing major health inequality trends for the nation, 1935-2016. Int J MCH AIDS. 2017;6(2):139-64.

47. Stockwell T, Giesbrecht N. Strategies to prevent alcohol-related injury targeted to high risk products, settings and populations. In: Cherpitel CJ, Borges G, Giesbrecht N, Monteiro M, Stockwell T, editors. Prevention of Alcohol-Related Injuries in the Americas: From evidence to policy action. Washington, DC: Pan American Health Organization; 2013. p. 149-58.

48. Room R, Graham K, Rehm J, Jernigan DH, Monteiro M. Drinking and its burden in a global perspective: policy considerations and options. Eur Addict Res. 2003 October;9(4):165-75.

49. Babor T, Caetano R, Casswell S, Edwards G, Giesbrecht N, Graham K, et al. Alcohol: No Ordinary Commodity: Research and public policy 2nd ed. New York: Oxford University Press; 2010.

50. Bloom DE, Chisholm D, Jané-Llopis E. From Burden to "Best Buys": Reducing the economicimpact of non-communicable diseases in lowand middle-income countries [Accessed: 2016-05-31. Archived by WebCite ${ }^{\circledR}$ at http://www.webcitation.org/6hvWLLp6G]. Geneva Switzerland: World Economic Forum, World Health Organization; 2011.

51. Kerr WC, Patterson D, Greenfield TK, Jones AS, McGeary KA, Terza JV, et al. U.S. alcohol affordability and real tax rates, 1950-2011. Am J Prev Med. 2013 May;44(5):459-64.

52. Naimi TS, Blanchette JG, Xuan Z, Chaloupka FJ. Erosion of state alcohol excise taxes in the United States. J Stu Alcohol Drugs. 2018 January;79(1):43-8.

53. Grossman ER, Kerr WC, Toomey TL. The role of law and policy in reducing deaths attributable to alcohol to reach healthy people's substance abuse goals in the United States. Rockville, MD: Department of Health and Human Services, Office of Disease Prevention and Health Promotion (ODPHP); 2020.

Manuscript received on 27 May 2020; revised version accepted for publication on 21 August 2020. 


\section{Tendencias cambiantes en las disparidades en las tasas de mortalidad por traumatismo no intencional en Estados Unidos entre 1999 y 2016}

RESUMEN Objetivos. Analizar cambios en las disparidades por raza y grupo étnico en materia de mortalidad por traumatismos no intencionales de 1999 al 2016.

Métodos. Los datos de mortalidad de todos los traumatismos no intencionales provienen del Centro Nacional de Estadísticas Sanitarias y se han analizado por separado por causa de traumatismo (colisiones automovilísticas, intoxicaciones y otras causas no intencionales) y por población blanca, negra e hispana, tanto en hombres como en mujeres, en cuatro grupos etarios: de 15 a 19, de 20 a 34, de 35 a 54 y de 55 a 74.

Resultados. Las tasas en todos los grupos raciales y étnicos variaron según el sexo, la edad y la causa del traumatismo. La mortalidad por traumatismo no intencional mostró un aumento reciente tanto en hombres como en mujeres, que fue más marcado en el caso de los hombres, y por intoxicación en todos los grupos raciales y étnicos de ambos sexos. La población blanca mostró las tasas más elevadas de mortalidad por intoxicación y el incremento más acentuado en ambos sexos, con excepción de los hombres negros entre 55 y 74 años de edad. La mortalidad por colisión automovilística también registró un aumento en todos los grupos raciales y étnicos, con un incremento mayor en la población negra, mientras que la población hispana mostró tasas inferiores que la blanca o la negra. Las tasas de mortalidad por otros traumatismos no intencionales fueron similares en todos grupos salvo en el caso de las mujeres blancas de más de 55 años, cuyas tasas mostraron un incremento.

Conclusiones. Los datos indican que, si bien la mortalidad por traumatismo no intencional relacionada con colisiones automovilísticas e intoxicación está en alza en ambos sexos y en la mayoría de los grupos etarios, la población negra en comparación con la blanca y la hispana puede estar presentando una carga desproporcionada de mortalidad relacionada con colisiones automovilísticas e intoxicación en personas mayores de 55, que podrían estar relacionado con el consumo de sustancias psicoactivas.

Palabras claves Lesiones accidentales; mortalidad; factores raciales; inequidad étnica; Estados Unidos.

\section{Mudança nos padrões de disparidade nas taxas de mortalidade por lesões acidentais nos Estados Unidos, 1999-2016}

RESUMO Objetivos. Analisar as mudanças nas disparidades étnico-raciais da mortalidade por lesões acidentais no período 1999-2016.

Métodos. Os dados de mortalidade foram obtidos do Centro Nacional de Estatísticas de Saúde (NCHS) dos Estados Unidos para todos os tipos de lesões acidentais e analisados em separado por causa de lesão (acidentes de trânsito de veículos a motor, envenenamento/intoxicação e outros tipos de acidentes) em grupos populacionais de brancos, negros e hispânicos de ambos os sexos divididos em quatro faixas etárias: 15-19, 20-34, 35-54 e 55-74 anos.

Resultados. As taxas de mortalidade nos grupos étnico-raciais variaram segundo sexo, idade e causa de lesão. Houve um aumento recente na mortalidade por lesões acidentais nos sexos masculino e feminino, sendo mais acentuado no sexo masculino e por envenenamento/intoxicação em todos os grupos étnicosraciais de ambos os sexos. A população branca apresentou as maiores taxas de mortalidade por envenenamento/intoxicação e o aumento mais acentuado na mortalidade em ambos os sexos, exceto por homens negros de 55-74 anos. Ocorreu também um aumento da mortalidade por acidentes de trânsito de veículos a motor em todos os grupos étnico-raciais, sendo mais acentuado em negros, e a mortalidade na população hispânica foi menor que em brancos ou negros. As taxas de mortalidade por outros tipos de acidentes foram semelhantes em todos os grupos, exceto em mulheres brancas acima de 55 anos que apresentaram taxas elevadas.

Conclusões. Os dados analisados indicam que, apesar de a mortalidade por lesões acidentais por acidentes de trânsito de veículos a motor e envenenamento/intoxicação estar aumentando em ambos os sexos e na maioria das faixas etárias, em comparação a brancos e hispânicos, os negros possivelmente sofrem um ônus desproporcional de mortalidade por acidentes de trânsito e envenenamento/intoxicação no grupo acima de 55 anos que pode estar associada ao uso de substâncias químicas.

Palavras-chave Lesões acidentais; mortalidade; fatores raciais; iniquidade étnica; Estados Unidos. 